Vol. VIII, No. 1, April 2015

P-ISSN: $1979-858 \mathrm{X}$

Halaman $78-89$

\title{
PENGARUH GOOD CORPORATE GOVERNANCE, KARAKTERISTIK PERUSAHAAN DAN REGULASI PEMERINTAH TERHADAP PENGUNGKAPAN CORPORATE SOCIAL RESPONSIBILITY
}

\author{
Wandayani Nurfadilah \\ Yusar Sagara \\ Jurusan Akuntansi UIN Syarif Hidayatullah Jakarta
}

\begin{abstract}
This objective of this study is to examine the good corporate governance, characteristics company and government regulations on the disclosure of corporate social responsibility on companies listed in the Indonesia Stock Exchange Period from 2010 to 2014. This study uses secondary data, annual reports obtained from www.idx.com and the company's website period 2010-2014. The sampling method of sample selection sampling cluster. The analytical method used is multiple regression analysis which consists of classical assumption (normality test, multicollinearity, heteroscedasticity test and autocorrelation test) and test hypotheses (coefficient of determination, $t$ test, $F$ test). The results that significantly influence the audit committee disclosure of CSR while managerial ownership, board size, profitability, liquidity, company profiles and government regulation has no effect on the disclosure of CSR. F Test results showed that the simultaneous effect of independent variables on the dependent variable.
\end{abstract}

Keywords: Good Corporate Governance, Corporate Characteristics, Government Regulation, Corporate Social Responsibility

ABSTRAK: Tujuan dari penelitian ini adalah untuk menguji hubungan kausalitas dari pengaruh good corporate governance, karakteristik perusahaan dan regulasi pemerintah terhadap pengungkapan corporate social responsibility pada perusahaan manufaktur yang terdaftar di Bursa Efek Indonesia Periode 2010-2014. Penelitian ini menggunakan data sekunder yaitu laporan tahunan perusahaan yang diperoleh dari www.idx.com dan website perusahaan selama periode 2010-2014. Proses pemilihan sampel dilakukan dengan menggunakan metode cluster sampling. Metode analisis yang digunakan adalah analisis regresi berganda yang terdiri dari uji asumsi klasik (uji normalitas, uji multikolinearitas, uji heteroskedastisitas, dan uji autokorelasi) dan uji hipotesis (koefisien determinasi, uji t, uji F). Hasil penelitian ini menunjukkan bahwa komite audit berpengaruh signifikan terhadap pengungkapan CSR sedangkan kepemilikan manajerial, ukuran dewan komisaris, profitabilitas, likuiditas, profil perusahaan dan regulasi pemerintah tidak berpengaruh terhadap pengungkapan CSR. Hasil Uji F menunjukan bahwa variabel independen berpengaruh secara simultan terhadap variabel dependen.

Kata kunci: Good Corporate Governance, Karakteristik Perusahaan, Regulasi Pemerintah, Corporate Social Responsibility

\footnotetext{
${ }^{1}$ Draft pertama: 05 Januari 2015 ; Revisi: 14 Februari 2015 ; Diterima: 10 Maret 2015

Penulis dapat dikontak melalui: yusar.9586@gmail.com
} 


\section{PENDAHULUAN}

Di Indonesia wacana mengenai CSR mulai mengemuka pada tahun 2001, namun sebelum wacana ini mengemuka telah banyak perusahaan yang menjalankan CSR dan sangat sedikit yang mengungkapkannya dalam sebuah laporan. Hal ini terjadi mungkin karena kita belum mempunyai sarana pendukung seperti standar pelaporan, tenaga terampil (baik penyusun laporan maupun auditornya). Di samping itu sektor pasar modal Indonesia juga kurang mendukung dengan belum adanya penerapan indeks yang memasukkan kategori saham-saham perusahaan yang telah mempraktikkan CSR. Sejak tanggal 23 september 2007, pengungkapan tanggung jawab sosial perusahaan (corporate social responsibility disclosure) mulai diwajibkan melalui UU Perseroan Terbatas Nomor 40 tahun 2007, khususnya untuk perusahaan-perusahaan yang hidup dari ekstraksi sumber daya alam (Nasir et al., 2013:2).

Kasus-kasus yang terkait dengan lingkungan yang dilakukan oleh perusahaan terhadap masyarakat dan lingkungan sekitar perusahaan, seperti kasus Lapindo yang dinobatkan sebagai perusahaan paling tidak bertanggung jawab sosial, kasus tuduhan pencemaran Teluk Buyat oleh PT Newmont Minahasa Raya serta kasus PT Freeport Indonesia yang akhirnya menyebabkan Kementerian Lingkungan Hidup pun mempublikasikan temuan pemantauan dan penataan kualitas lingkungan di wilayah penambangan PT Freeport Indonesia yang hasilnya, Freeport dinilai tak memenuhi batas air limbah dan telah mencemari air laut dan biota laut, mendorong pemerintah untuk menerbitkan regulasi yang mengatur tentang corporate social responsibility (selanjutnya disebut CSR) yaitu UU No. 40 Tahun 2007 tentang Perseroan Terbatas (Arifin et al., 2011:1).

Dalam Pasal 74 Undang-Undang tersebut diatur tentang kewajiban pengungkapan tanggung jawab sosial dan lingkungan perusahaan.Pertanggungjawaban sosial perusahaan atau Corporate Sosial Responsibility (CSR) merupakan suatu tindakan atau konsep yang dilakukan oleh perusahaan (sesuai kemampuan perusahaan tersebut) sebagai bentuk tanggung jawab mereka terhadap sosial dan lingkungan sekitar dimana perusahaan itu berada. Contoh bentuk tanggung jawab itu bermacam-macam, mulai dari melakukan kegiatan yang dapat meningkatkan kesejahteraan masyarakat dan perbaikan lingkungan, pemberian dana untuk pemeliharaan fasilitas umum, sumbangan untuk desa atau fasilitas masyarakat yang bersifat sosial dan berguna untuk masyarakat banyak, khususnya masyarakat yang berada disekitar perusahaan tersebut (Nasir et al., 2013:3).

Belum semua perusahaan melakukan Tanggung Jawab Sosial (CSR), melaporkan dan mengungkapkan kegiatan Tanggung Jawab Sosialnya. Berdasarkan penelitian yang dilakukan oleh KAP KPMG persentase perusahaan yang melaporkan pada inisiatif CSR 2008-2011 meningkat dari 74\% menjadi 83\% di Amerika Serikat, dari 62\% menjadi 79\% di Kanada, dan dari 91\% menjadi 100\% di Inggris. Berdasarkan survei tersebut dapat dilihat persentase peningkatan perusahaan yang melaporkan pada inisiatif CSR di wilayah Amerika dan Inggris mengalami peningkatan $9 \%$, sedangkan di wilayah Kanada mengalami peningkatan $17 \%$ selama 4 tahun (KPMG, 2011 dalam Sagara, 2014:1).

Fenomena yang terjadi di Indonesia konsep CSR sudah mulai disadari perusahaanperusahaan besar, contohnya program community development yang dijalankan hampir semua perusahaan besar maupun Program Kemitraan dan Bina Lingkungan (PKBL) oleh Badan Usaha Milik Negara (BUMN) menjadi bukti bagaimana korporasi menerangkan konsep CSR, juga penerapan CSR oleh Hongkong and Shanghai Banking Corporation Limited (HSBC) yang memberikan perhatian khusus di bidang pendidikan, lingkungan hidup, dan sosial (Sagara, 2014:1).

Penelitian ini merupakan pengembangan dari penelitian sebelumnya, yaitu penelitian dari Sartawi et al., (2014), Nasir et al., (2013), Ramdhaningsih dan Utama (2013), Sari et al., 
(2013), Wakid et al., (2012), Lucyanda dan Siagian (2012), Utami dan Prastiti (2011), dan Mutia et al., (2011).

Berdasarkan latar belakang tersebut, maka masalah yang dapat dirumuskan adalah sebagai berikut.

1. Pengaruh kepemilikan manajerial terhadap pengungkapan CSR.

2. Pengaruh komite audit terhadap pengungkapan CSR.

3. Pengaruh dewan komisaris terhadap pengungkapan CSR.

4. Pengaruh profitabilitas terhadap pengungkapan CSR.

5. Pengaruh likuiditas terhadap pengungkapan CSR.

6. Pengaruh profil perusahaan terhadap pengungkapan CSR.

7. Pengaruh regulasi pemerintah terhadap pengungkapan CSR.

8. Pengaruh kepemilikan manajerial, komite audit, dewan komisaris, profitabilitas, likuiditas, profil perusahaan danregulasi pemerintah secara simultan terhadap pengungkapan CSR.

Penelitian ini bertujuan untuk menganalisa hubungan kausalitas yang digunakan untuk menjelaskan pengaruh good corporate governance (yang diproksikan dengan kepemilikan manajerial, komite audit dan ukuran dewan komisaris), karakteristik perusahaan (yang diproksikan dengan profitabilitas, likuiditas, profil perusahaan) dan regulasi pemerintah terhadap pengungkapan corporate social responsibility. Populasi penelitianadalah perusahaan manufaktur yang terdaftar di Bursa Efek Indonesia periode 2010-2014.

\section{KERANGKA TEORI DAN PENGEMBANGAN HIPOTESIS}

\section{Pengungkapan CSR}

Corporate Sosial Responsibility (CSR) adalah bentuk tanggung jawab dari setiap perusahaan terhadap lingkungan terutama kemungkinan kerusakan lingkungan yang semakin parah, sehingga anak cucu kita kelak tidak semakin menanggung beban yang lebih berat dibandingkan dengan generasi sekarang (Saiman, 2009:297)

Pengungkapan adalah pengeluaran informasi yang ditujukan bagi pihak-pihak yang berkepentingan. Tujuan dari pengungkapan corporate social responsibility (CSR) adalah agar perusahaan dapat menyampaikan tanggung jawab sosial yang telah dilaksanakan perusahaan dalam periode tertentu.Penerapan corporate social responsibility (CSR) dapat diungkapkan perusahaan dalam media laporan tahunan (annual report) perusahaan yang berisi laporan tanggung jawab sosial perusahaan selama kurun waktu satu tahun berjalan (Sari, 2012:128).

\section{Kepemilikan Manajerial}

Kepemilikan manajerial adalah para pemegang saham yang juga berarti dalam hal ini sebagai pemilik dalam perusahaan dari pihak manajemen yang secara aktif ikut dalam pengambilan keputusan pada suatu perusahaan yang bersangkutan, yang biasanya dinyatakan sebagai persentase saham perusahaan yang beredar yang dimiliki oleh orang dalam perusahaan yaitu manajer, komisaris dan direksi (Domash, 2009 dalam Priantana et al.,2011:3).

$\mathbf{H}_{\mathbf{1}}$ : Kepemilikan manajerial berpengaruh terhadap pengungkapan corporate social responsibility.

\section{Komite Audit}

Komite audit merupakan komite yang membantu komisaris atau dewan pengawas dalam memastikan efektivitas sistem pengendalian internal dan efektifitas pelaksanaan 
tugas auditor eksternal dan internal (Alijoyo, 2003 dalam Priantana et al., 2011:4). Berdasarkan strukturnya, komite audit sekurang-kurangnya terdiri dari tiga anggota. Salah satunya dari anggota tersebut merupakan komisaris independen yang sekaligus merangkap sebagai ketua, sedangkan anggota lainnya merupakan pihak eksternal yang independen (SE Ketua Bapepam Nomor SE-03/PM/200o dalam Priantana etal., 2011:4).

$\mathbf{H}_{2}$ : Komite audit berpengaruh terhadap pengungkapan corporate social responsibility.

\section{Ukuran Dewan Komisaris}

Ukuran dewan komisaris adalah jumlah anggota dewan komisaris.Dewan komisaris adalah mekanisme pengendalian internal tertinggi yang bertanggung jawab untuk mengelola perusahaan secara efektif (Mutia et al., 2011:4).

$\mathbf{H}_{3}$ : Ukuran dewan komisaris berpengaruh terhadap pengungkapan corporate social responsibility.

\section{Profitabilitas}

Kusnadi et al., (2002) dalam Wakid et al., (2012: 7) menjelaskan bahwa profitabilitas merupakan hasil akhir dari keseluruhan kebijakan dan keputusan yang dipilih oleh manajemen organisasi bisnis. Seluruh kebijakan apapun yang ada di dalam organisasi jika berjalan baik dan berdampak positif akan menghasilkan kinerja yang efektif dan efisien sehingga akan menghasilkan tingkat keuntungan perusahaan yang memuaskan. Menurut Lucyanda dan Siagian (2012:604):

$\mathrm{H}_{4}$ : Profitabilitas berpengaruh terhadap pengungkapan corporate social responsibility.

\section{Likuiditas}

Likuiditas saham menurut Bursa Efek Indonesia (Informasi Umum Pasar Modal, Stock Exchange) dalam Santoso dan Linawati (2014:59) adalah kelancaran yang menunjukan tingkat kemudahan dalam mencairkan modal investasi. Secara umum, Sharpeet al., (1999) dalam Santoso dan Linawati (2014:59) mendefinisikan likuiditas sebagai kemampuan investor menjual harta atau asset yang dimilikinya tanpa harus melakukan konsesi atau kelonggaran harta.

$\mathbf{H}_{5}$ : Likuiditas berpengaruh terhadap pengungkapan corporate social responsibility.

\section{Profil Perusahaan}

Profil perusahaan adalah uraian tentang bidang operasi yang dijalankan oleh perusahaan (Rahman dan Widyasari, 2008 dalam Wakid, et al., 2012:8). Hubungan antara profil perusahaan dengan pengungkapan tanggung jawab sosial dapat dikaitkan dengan variasi dampak operasi perusahaan terhadap lingkungan dan masyarakat. Industri high profile sebagai industri yang memiliki consumer visibility, risiko politik yang tinggi, atau kompetisi yang tinggi akan lebih memperhatikan pertanggungjawaban sosialnya kepada masyarakat karena hal ini akan meningkatkan citra perusahaan dan dapat memengaruhi tingkat penjualan

$\mathbf{H}_{6}$ : Profil perusahaan berpengaruh terhadap pengungkapan corporate social responsibility. 


\section{Regulasi Pemerintah}

Menurut Coghill (1999) dalam Basuki dan Patrioty (2011:26) regulasi pemerintah dapat dipahami sebagai bagian yang tidak dapat dipisahkan dari lingkungan perusahaan, sebab sebagai badan pembuat peraturan (Regulatory Body) pemerintah memiliki peran signifikan terhadap kebijakan yang dibuat oleh perusahaan terhadap lingkungan eksternalnyaPemerintah Indonesia melalui undang-undang Perseroan Terbatas UU No 40 Tahun 2007 menginsyaratkan bahwa secara eksplisit peran yang dilakukan pemerintah adalah pada peran mandating.

$\mathrm{Ha}_{7}$ : Regulasi pemerintah berpengaruh terhadap pengungkapan corporate social responsibility.

Berdasarkan latar belakang masalah di atas dan landasan teori yang telah dipaparkan sebelumnya, maka model penelitian ini dapat digambarkan sebagai berikut.

Variabel Independen

Kepemilikan Manajerial $\left(\mathrm{X}_{1}\right)$

(Priantana et al., (2010) dan Saraswati et al., (2012))

Komite Audit $\left(\mathrm{X}_{2}\right)$

(Priantana et al., (2010) dan Saraswati et al., (2012))

Ukuran Dewan Komisaris $\left(\mathrm{X}_{3}\right)$

(Priantana et al., (2010), Mutia et al., (2011) )

Profitabilitas $\left(\mathrm{X}_{4}\right)$

(Sari (2012), Mutia et al., (2011), Nurkhin(2009))

Likuiditas $\left(\mathrm{X}_{5}\right)$

Laksmitaningrum dan Purwanto (2013)

Profil Perusahaan $\left(\mathrm{X}_{6}\right)$

Wakid et al., (2012)

Regulasi Pemerintah $\left(\mathrm{X}_{7}\right)$

Basuki dan Patrioty (2009)
Variabel Dependen

\section{METODE PENELITIAN}

Penelitian ini menggunakan populasi perusahaan manufaktur yang terdaftar di Bursa Efek Indonesia (BEI) selama periode 2010-2014. Fokus penelitian ini adalah ingin melihat pengaruh goodcorporate governance yang diproksikan oleh kepemilikan manajerial; komite audit dan ukuran dewan komisaris, karakteristik perusahaan yang diproksikan oleh profitabilitas, likuiditas, dan profil perusahaan sertaregulasi pemerintah terhadap pengungkapan corporate social responsibility (CSR) pada perusahaan manufaktur.

Dalam penelitian ini metode yang digunakan untuk memilih sampel adalah metode cluster sampling. Penelitian ini mengambil sampel selama 5 tahun, yaitu dari tahun 20102014. Penelitian secara cluster sampling mengindikasikan bahwa sampel yang digunakan dalam penelitian ini merupakan representasi dari populasi yang ada, serta sesuai dengan tujuan dari penelitian. Data yang digunakan yaitu diambil dari annual report pada tahun 
2010, 2011, 2012, 2013 dan 2014 yang diakses melalui website www.idx.co.id dan website perusahaan.

Adapun proses seleksi sampel berdasarkan cluster adalah sebagai berikut. Pada tahap awal, data perusahaan manufaktur dibagi menjadi 5 cluster berdasarkan tahun sehingga tahun dapat disebut sebagai primary sampling unit (PSU) dengan sample fraction :

$$
\mathrm{f}_{1}=\frac{5}{5}=1
$$

Pada tahap kedua peneliti mengelompokan data secara proposional dengan sample fraction $\mathrm{f}_{2}=20 \%$, artinya perusahaan manufaktur yang dipilih sebagai sampel adalah sebanyak $20 \%$ dari jumlah perusahaan manufaktur di setiap tahunnya.

$$
\begin{array}{llll}
\mathrm{n} 2 \mathrm{O10} & \frac{20}{100} \times 128 & = & 26 \\
\mathrm{n} 2 \mathrm{O11} & =\frac{20}{100} \times 130 & = & 26 \\
\mathrm{n} 2012 & =\frac{20}{100} \times 132 & = & 26 \\
\mathrm{n} 2013 & =\frac{20}{100} \times 136 & = & 27 \\
\mathrm{n} 2014 & \frac{20}{100} \times 173 & = & 35
\end{array}
$$

Jumlah sampel untuk tahap kedua adalah 140 perusahaan. Untuk memilih 140 perusahaan tersebut dilakukan secara random.

Dalam penelitian ini, peneliti menggunakan data outlier yang berakibat pada tereliminasinya 20 perusahaan dari daftar sampel dan untuk melanjutkan ke tahap selanjutnya sampel yang tersisa adalah sebanyak 120 perusahaan.Adapun persamaan untuk menguji hipotesis pada penelitian ini adalah sebagai berikut:

$$
\begin{aligned}
\text { CSRDI }=\alpha+\beta_{1} \mathrm{KM}+ & \beta_{2} \mathrm{KA}+\beta_{3} \mathrm{UDK}+\beta_{4} \mathrm{ROA}+\beta_{5} \mathrm{LQD}+\beta_{6} \mathrm{PP}+\beta_{8} \mathrm{REG}+\varepsilon \\
\text { Dimana; } \mathrm{CSRDI} & =\text { Corporate Social Responsibility Disclosure Index } \\
\mathrm{KM} & =\text { Kepemilikan Manajerial } \\
\mathrm{KA} & =\text { Komite Audit } \\
\mathrm{UDK} & =\text { Ukuran Dewan Komisaris } \\
\mathrm{ROA} & =\text { Return on Assets } \\
\mathrm{LQD} & =\text { Likuiditas } \\
\mathrm{PP} & =\text { Profil Perusahaan } \\
\mathrm{REG} & =\text { Regulasi Pemerintah } \\
\alpha & =\text { intercept } \\
\beta_{1}, \ldots, \beta_{8} & =\text { koefisien regresi } \\
\varepsilon & =\text { error }
\end{aligned}
$$

Berikut adalah indikator yang digunakan untuk mengukur masing-masing variabel. 


\begin{tabular}{|c|c|c|}
\hline & saham yang dimiliki direksi dan komisaris & \multirow[t]{2}{*}{ Rasio } \\
\hline & total saham & \\
\hline $\begin{array}{l}\text { Komite Audit } \\
\text { (Saraswati et al., } \\
\text { 2012) }\end{array}$ & Jumlah Anggota Komite Audit & Rasio \\
\hline $\begin{array}{l}\text { Ukuran Dewan } \\
\text { Komisaris } \\
\text { (Nur et al., 2012) }\end{array}$ & Jumlah Anggota Dewan Komisaris & Rasio \\
\hline $\begin{array}{l}\text { Profitabilitas } \\
\text { (Nurkhin, 2009) }\end{array}$ & $\frac{\text { Net Income }}{\text { Shareholder's Equity }}$ & Rasio \\
\hline $\begin{array}{l}\text { Likuiditas } \\
\text { (Laksmitaningrum } \\
\text { dan Purwanto, } \\
\text { 2013) }\end{array}$ & $\frac{\text { Current Assets }}{\text { Current Liabilities }}$ & Rasio \\
\hline $\begin{array}{l}\text { Profil Perusahaan } \\
\text { (Rahman dan } \\
\text { Widyasari, 2008). }\end{array}$ & $\begin{array}{l}\text { Bidang operasi yang dijalankan oleh } \\
\text { perusahaan;High profile (1)Low profile (o) }\end{array}$ & Nominal \\
\hline $\begin{array}{l}\text { Regulasi } \\
\text { Pemerintah }\end{array}$ & $\begin{array}{l}\text { Mengungkapkan annual report (1) } \\
\text { Tidak mengungkapkan annual report (o) }\end{array}$ & Nominal \\
\hline $\begin{array}{l}\text { Pengungkapan } \\
\text { Corporate Social } \\
\text { Responsibility } \\
\text { (Nurkhin, 2009) }\end{array}$ & $\operatorname{CSRDI}_{\mathrm{j}}=\frac{\sum \mathrm{X}_{\mathrm{ij}}}{78}$ & Rasio \\
\hline
\end{tabular}

\section{HASIL DAN PEMBAHASAN}

\section{Hasil Uji Asumsi Klasik}

Hasil Uji Normalitas

Dapat dilihat dari tabel 4 bahwa besarnya nilai Kolmogorov Smirnov adalah 1,329 dan signifikansi pada 0,059 hal ini berarti data residual terdistribusi normal

Tabel 4. Hasil Uji Normalitas

One-Sample Kolmogorov-Smirnov Test

\begin{tabular}{|ll|r|}
\hline & & $\begin{array}{r}\text { Unstandardized } \\
\text { Residual }\end{array}$ \\
\hline $\mathrm{N}$ & Mean & $\mathbf{1 2 0}$ \\
Normal Parameters ${ }^{\mathrm{a}, \mathrm{b}}$ & Std. Deviation &, 0000000 \\
& Absolute & $\mathbf{0 2 2 3 0 9 6 1}$ \\
Most Extreme Differences & Positive &, 121 \\
& Negative & $\mathbf{1 2 1}$ \\
Kolmogorov-Smirnov Z & & $\mathbf{0} 80$ \\
Asymp. Sig. (2-tailed) & & 1,329 \\
\hline
\end{tabular}

a. Test distribution is Normal.

b. Calculated from data. 


\section{Hasil Uji Multikonilearitas}

Berdasarkan tabel 5, terlihat bahwa nilai tolerance untuk semua variabel independen lebih dari o,10 dan nilai VIF (Variance Inflation Factor) semua variabel independen kurang dari 10. Dengan demikian dapat dikatakan bahwa model persamaan regresi mengindikasikan tidak terjadi adanya multikolonieritas.

Tabel 5. Hasil Uji Multikolinearitas

Coefficients $^{\mathrm{a}}$

\begin{tabular}{|c|c|c|c|c|c|c|c|}
\hline \multirow[t]{2}{*}{ Model } & \multicolumn{2}{|c|}{$\begin{array}{c}\text { Unstandardized } \\
\text { Coefficients }\end{array}$} & \multirow{2}{*}{ 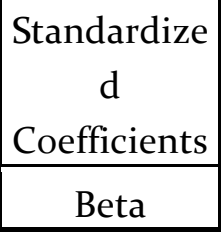 } & \multirow[t]{2}{*}{$\mathrm{t}$} & \multirow[t]{2}{*}{ Sig. } & \multicolumn{2}{|c|}{$\begin{array}{l}\text { Collinearity } \\
\text { Statistics }\end{array}$} \\
\hline & B & Std. Error & & & & Tolerance & VIF \\
\hline (Constant & ,014 & , 007 & & 2,009 & ,047 & & \\
\hline KM &,- 027 & 119 &,- 019 &,- 232 & ,817 & ,945 & 1,058 \\
\hline KA & , 007 & ,003 & ,335 & 2,101 & ,038 & ,253 & 3,956 \\
\hline UDK & , oo1 & ,002 & , o68 & ,541 & ,590 & ,403 & 2,484 \\
\hline $\mathrm{ROA}$ & ,036 & ,029 & ,117 & 1,246 & ,215 & ,728 & 1,374 \\
\hline LQD & ,oor & ,002 & , 039 & ,394 & ,694 & ,673 & 1,485 \\
\hline PP &,- 002 & ,005 &,- 037 &,- 416 & 678 & ,797 & 1,255 \\
\hline REG & ,005 & , 010 & , 070 & ,498 & 619 &, 326 & 3,070 \\
\hline
\end{tabular}

a. Dependent Variable: CSR

\section{Hasil Uji Heteroskedastisitas (Uji Glejser)}

Tabel 6 menunjukan bahwa semua variabel memiliki nilai signifikansi lebih dari o,05 yang artinya tidak ada satupun variabel independen yang signifikan secara statistik mempengaruhi variabel dependen nilai Absolut Residual (abs_resı). Jadi dapat disimpulkan bahwa model regresi tidak mengandung adanya heteroskedastisitas.

Tabel 6. Hasil Uji Heteroskedastisitas Coefficients $^{\mathrm{a}}$

\begin{tabular}{|c|c|c|c|c|c|}
\hline \multirow[t]{2}{*}{ Model } & \multicolumn{2}{|c|}{ Unstandardized Coefficients } & \multirow{2}{*}{\begin{tabular}{|c|} 
Standardized Coefficients \\
Beta
\end{tabular}} & \multirow[t]{2}{*}{$t$} & \multirow[t]{2}{*}{ Sig. } \\
\hline & $\mathrm{B}$ & Std. Error & & & \\
\hline (Constant) & ,020 & ,004 & & 5,173 &, 000 \\
\hline KM &,- 126 & ,069 &,- 169 & $-1,839$ & 069 \\
\hline KA &, 000 & ,002 &,- 028 &,- 159 & 874 \\
\hline 1 UDK & 001 & 001 & ,099 &, 705 & ,483 \\
\hline ROA & ,027 & ,017 & ,167 & 1,592 & ,114 \\
\hline LQD &, 001 & 001 &, 155 & 1,423 & , 157 \\
\hline PP &,- 002 & ,003 &,- 085 &,- 849 & ,398 \\
\hline REG &,- 007 &, 006 &,- 187 & $-1,196$ & ,234 \\
\hline
\end{tabular}

a. Dependent Variable: ABS_RES1

\section{Hasil Uji Autokorelasi}


Hasil uji autokorelasi dengan menggunakan Durbin Watson berdasarkan pada tabel 7 menunjukan angka 1,761 yaitu diantara -2 sampai +2 yang artinya bahwa tidak terjadi autokorelasi baik negatif atau positif sehingga Ho tidak dapat ditolak.

Tabel 7. Hasil Uji Autokorelasi

\begin{tabular}{|l|r|r|r|r|r|}
\hline $\begin{array}{l}\text { Mode } \\
1\end{array}$ & $\mathrm{R}$ & R Square & $\begin{array}{c}\text { Adjusted R } \\
\text { Square }\end{array}$ & $\begin{array}{r}\text { Std. Error of } \\
\text { the Estimate }\end{array}$ & $\begin{array}{l}\text { Durbin- } \\
\text { Watson }\end{array}$ \\
\hline 1 &, $527^{\mathrm{a}}$ &, 278 &, 233 &, 0229962 & 1,761 \\
\hline
\end{tabular}

a. Predictors: (Constant), REG, KM, ROA, PP, LQD, UDK, KA

b. Dependent Variable: CSR

\section{Hasil Uji Hipotesis}

\section{Koefisien Determinasi}

Hasil pengujian pada tabel 8 menunjukan bahwa $\mathrm{R}^{2}$ sebesar 0,233 atau 23,3\%. Jadi dapat dikatakan bahwa sebesar $23,3 \%$ pengungakapan corporate social responsibility pada perusahaan manufaktur yang terdaftar di Bursa Efek Indonesia periode 2010-2014 disebabkan oleh kepemilikan manajerial, komite audit, ukuran dewan komisaris, profitabilitas, likuiditas, profil perusahaan dan regulasi pemerintah.

Tabel 8. Hasil Uji Autokorelasi Model Summary ${ }^{b}$

\begin{tabular}{|l|r|r|r|r|}
\hline $\begin{array}{l}\text { Mode } \\
1\end{array}$ & \multicolumn{1}{|c|}{$\mathrm{R}$} & R Square & $\begin{array}{c}\text { Adjusted R } \\
\text { Square }\end{array}$ & $\begin{array}{r}\text { Std. Error of } \\
\text { the Estimate }\end{array}$ \\
\hline 1 &, $527^{\mathrm{a}}$ &, 278 &, 233 &, 0229962 \\
\hline
\end{tabular}

a. Predictors: (Constant), REG, KM, ROA, PP, LQD, UDK, KA

b. Dependent Variable: CSR

\section{Hasil Uji Signifikansi Parameter Individual (Uji t)}

Berdasarkan tabel, hasil uji t dapat dijelaskan sebagai berikut.

1. Hasil uji regresi linier berganda menunjukkan signifikansi o,817 > 0,05. Dapat diartikan bahwa kepemilikan manajerial tidak berpengaruh terhadap pengungkapan corporate social responsibility. Hasil yang sama juga ditemukan dalam penelitian yang dilakukan oleh Nazir et al., (2013) Mutia et al., (2011).

2. Hasil uji regresi linier berganda menunjukkan signifikansi 0,038<0,05. Dapat diartikan bahwa komite audit berpengaruh terhadap pengungkapan corporate social responsibility. Hasil yang sama juga ditemukan dalam penelitian yang dilakukan oleh Susanti dan Rihardjo (2013).

3. Hasil uji regresi linier berganda menunjukan signifikansi o,590. Dapat diartikan bahwa ukuran dewan komisaris tidak berpengaruh terhadap pengungkapan corporate social responsibility. Hasil yang sama juga ditemukan dalam penelitian yang dilakukan oleh Wakid et al., (2012).

4. Hasil uji regresi linier berganda menunjukkan signifikansi 0,215 >0,05. Dapat diartikan bahwa profitabilitas tidak berpengaruh terhadap pengungkapan corporate 
social responsibility. Hasil yang sama juga ditemukan dalam penelitian yang dilakukan oleh Nazir et al., (2013) dan Wakid et al., (2012).

5. Hasil uji regresi linier berganda menunjukkan o,694 > 0,05. Dapat diartikan bahwa likuiditas tidak berpengaruh terhadap pengungkapan corporate social responsibility. Hasil yang sama juga ditemukan dalam penelitian yang dilakukan oleh Kamil dan Herusetya (2012).

6. Hasil uji regresi linier berganda menunjukkan signifikansi o,678 > 0,05. Dapat diartikan bahwa profil perusahaan tidak berpengaruh terhadap pengungkapan corporate social responsibility. Hasil yang sama juga ditemukan dalam penelitian yang dilakukan oleh Wakid et al., (2013).

7. Hasil uji regresi linier berganda menunjukkan signifikansio,619 $>0,05$. Dapat diartikanbahwa regulasi pemerintah tidak berpengaruh terhadap pengungkapan corporate social responsibility. Hasil yang sama juga ditemukan dalam penelitian yang dilakukan oleh Basuki dan Patrioty (2011).

8. Hasil uji regresi linier berganda secara simultan menunjukkan signifikansi $0,00<0,05$. Dapat diartikan bahwa kepemilikan manajerial, komite audit, ukuran dewan komisaris, profitabilitas, likuiditas, prpofil perusahaan dan regulasi pemerintah secara simultan berpengaruh terhadap pengungkapan corporate social responsibility.

Tabel 11. Hasil Uji Signifikansi Parameter Individual (Uji t)

\section{Coefficients $^{\text {a }}$}

\begin{tabular}{|c|c|c|c|c|c|c|}
\hline & \multirow[t]{2}{*}{ Model } & \multicolumn{2}{|c|}{$\begin{array}{c}\text { Unstandardized } \\
\text { Coefficients }\end{array}$} & \multirow{2}{*}{\begin{tabular}{|c}
$\begin{array}{c}\text { Standardize } \\
\mathrm{d} \\
\text { Coefficients }\end{array}$ \\
Beta
\end{tabular}} & \multirow[t]{2}{*}{$\mathrm{t}$} & \multirow[t]{2}{*}{ Sig. } \\
\hline & & B & $\begin{array}{l}\text { Std. } \\
\text { Error }\end{array}$ & & & \\
\hline & $\begin{array}{c}\text { (Consta } \\
\text { nt) }\end{array}$ & ,014 & ,007 & & 2,009 & , 047 \\
\hline & KM &,- 027 & 119 &,- 019 &,- 232 & ,817 \\
\hline & KA & ,007 & ,003 & ,335 & 2,101 & ,038 \\
\hline 1 & UDK & ,001 & ,002 & , o68 & ,541 & ,590 \\
\hline & ROA & ,036 & ,029 & 117 & 1,246 & ,215 \\
\hline & LQD & ,001 & ,002 & , 039 & ,394 & 694 \\
\hline & PP &,- 002 & ,005 &,- 037 &,- 416 & ,678 \\
\hline & REG & ,005 & ,010 & , 070 & ,498 & ,619 \\
\hline
\end{tabular}

a. Dependent Variable: CSR

\section{Hasil Uji Signifikansi Parameter Simultan (Uji F)}

Tabel 9 menunjukan hasil uji statistik F terhadap variabel-variabel independen dan variabel dependen. Tabel tersebut menunjukkan bahwa kepemilikan manajerial, komite audit, ukuran dewan komisaris, profitabilitas, likuiditas, profil perusahaan dan regulasi pemerintah secara simultan berpengaruh terhadap pengungkapan corporate social responsibility. Hal tersebut dibuktikan dengan tingkat signifikansi o,ooo lebih kecil dari o,o 
Tabel 1o. Hasil Uji Signifikansi Parameter Simultan (Uji F)

\begin{tabular}{|c|c|c|c|c|c|c|}
\hline \multicolumn{7}{|c|}{ ANOVA $^{\mathrm{a}}$} \\
\hline \multicolumn{2}{|c|}{ Model } & $\begin{array}{l}\text { Sum of } \\
\text { Squares }\end{array}$ & $\mathrm{df}$ & $\begin{array}{l}\text { Mean } \\
\text { Square }\end{array}$ & F & Sig. \\
\hline \multirow{3}{*}{1} & Regression & ,023 & 7 & ,003 & 6,162 &, $\mathrm{ooo}^{\mathrm{b}}$ \\
\hline & Residual & , 059 & 112 & , ool & & \\
\hline & Total & ,082 & 119 & & & \\
\hline
\end{tabular}

a. Dependent Variable: CSR

b. Predictors: (Constant), REG, KM, ROA, PP, LQD, UDK, KA

\section{SIMPULAN}

Dapat disimpulkan bahwa kepemilikan manajerial, komite audit, ukuran dewan komisaris, profitabilitas, likuiditas, profil perusahaan dan regulasi pemerintah secara simultan berpengaruh terhadap pengungkapan corporate social responsibility. Namun secara parsial hanya komite audit yang berpengaruh signifikan terhadap pengungkapan corporate social responsibility.

\section{PUSTAKA ACUAN}

Arifin, Bustanul, Yeni Januarsi dan Faoziah Ulfah. "Perbedaan Kecenderungan Pengungkapan Corporate Social Responsibility : Pengujian Terhadap Manipulasi Akrual Dan Manipulasi Real”. Jurnal Universitas Sultan Ageng Tirtayasa, 2012.

Basuki dan Corry Natasha Patrioty."Pengaruh Regulasi Pemerintah, Tekanan Masyarakat, Tekanan Organisasi Lingkungan, Tekanan Media Massa, Terhadap Corporate Social Disclosure". Ekuitas Vol. 15 No. 1 Maret 2011: 23 - 39.

Ghozali, Imam. "Aplikasi Analisis Multivariate dengan Program IBM SPSS". Edisi Ke-Lima, Universitas Diponegoro Semarang, 2011.

Kamil, Ahmad dan Antonius Herusetya. "Pengaruh Karakteristik Perusahaan Terhadap Luas Pengungkapan Kegiatan Corporate Social Responsibility. Media Riset Akuntansi, Vol. 2 Nomor 1, 2012.

Laksmitaningrum, Chintya Fadila dan Agus Purwanto. "Analisis Pengaruh Karakteristik Perusahaan, Ukuran Dewan Komisaris Dan Struktur Kepemilikan Terhadap Pengungkapan CSR (Studi Empiris Pada Perusahaan Manufaktur Yang Terdaftar Di Bursa Efek Indonesia Tahun 2009-2011)", Diponegoro Journal Of Accounting, Volume 2, Nomor 3, 2013.

Lucyanda, Jurica dan Lady Gracia Prilia Siagian."The Influence of Company Characteristics Toward Corporate Social Responsibility Disclosure”.The 2012 International Conference on Business and Management 6 - 7 September, Phuket -Thailand. Bakrie University, Jakarta-Indonesia, 2012.

Mutia, Evi, Zuraida, dan Devi Andriani. "Pengaruh Ukuran Perusahaan, Profitabilitas dan Ukuran Dewan Komisaris terhadap Pengungkapan Corporate Social Responsibility pada Perusahaan Manufaktur yang Terdaftar di Bursa Efek Indonesia". Jurnal Telaah \& Riset Akuntansi, Vol. 4. No. 2 Juli hal. 187 - 201. Universitas Syiah Kuala, 2011.

Nasir, Azwir, Pipin Kurnia dan Teguh Dheki Hakri. "Pengaruh Kepemilikan Manajerial, Leverage, Profitabilitas, Ukuran, dan Umur Perusahaan Terhadap Pengungkapan Informasi Pertanggungjawaban Sosial Perusahaan Pada Perusahaan Food And Beverage Yang Terdaftar di BEI". Jurnal Ekonomi Volume 21, Nomor 4, 2013. 
Nurkhin, Ahmad. "Corporate Governance dan Profitabilitas; Pengaruhnya terhadap Pengungkapan Tanggung Jawab Sosial Perusahaan (Studi Empiris pada Perusahaan yang Tercatat di Bursa Efek Indonesia)”. TESIS. Universitas Diponegoro, 2009.

Priantana, Riha Dedi dan Ade Yustian."Pengaruh Struktur Good Corporate Governance terhadap Pengungkapan Corporate Social Responsibility pada Perusahaan Keuangan yang Terdaftar di Bursa Efek Indonesia".Jurnal Telaah \& Riset Akuntansi.Vol. 4.No. 1, Januari hal.65-78. Universitas Syiah Kuala, 2011.

Ramdhaningsih, Amalia dan I Made Karya Utama. "Indikator Good Corporate Governance dan Profitabilitas Pada Pengungkapan Corporate Social Responsibility". E-Jurnal Akuntansi Universitas Udayana, 2013.

Sagara, Yusar. "Pengaruh Pelaporan dan Pengungkapan Aktivitas Tanggung Jawab Sosial Perusahaan (Corporate Social Responsibility) Terhadap Kualitas Lingkungan Hidup Perusahaan Manufaktur di Indonesia. LP3M UIN Syarif Hidayatullah Jakarta, 2014.

Saiman, Leonardus. "Kewirausahaan (Teori, Praktik dan Kasus-kasus)". Salemba Empat Jakarta, 2009.

Santoso, Halim dan Nanik Linawati. "Pengaruh Return dan Varian Return Anggota LQ-45 Terhadap Bid-Ask Spread”. FINESTA Vol. 2, No. 2, 2014.

Saraswati, Rara dan Basuki Hadiprajitno."Pengaruh Corporate Governance pada hubungan Corporate Social Responsibility dan Nilai Perusahaan Manufaktur yang terdaftar di $B E I$ ". Jurnal Akuntansi \& Auditing Volume 9/No.1/ hal: 1-96. Universitas Diponegoro. 2012.

Sari, Ati Retna, Sutrisno, dan Eko Ganis Sukoharsono. "Pengaruh Kepemilikan Institusional, Komposisi Dewan Komisaris, Kinerja Perusahaan terhadap Luas Pengungkapan Corporate Social Responsibility di dalam Sustainability Report pada Perusahaan Manufaktur yang Terdaftar di BEI". Jurnal Aplikasi Manajemen, Volume 11 Nomor 3, 2013,

Sari, Rizkia Anggita."Pengaruh Karakteristik Perusahaan terhadap Corporate Social Responsibility Disclosure pada Perusahaan Manufaktur yang terdaftar di Bursa Efek Indonesia".Jurnal Nominal/ Volume I Nomor I. Universitas Negeri Yogyakarta, 2012.

Sartawi, Iaad I. S. Mustafa, dkk. "Board Composition, Firm Characteristics, and Voluntary Disclosure: The Case of Jordanian Firms Listed on the Amman Stock Exchange". International Business Research; Vol. 7, No. 6; 2014.

Utami, Sri dan Sawitri Dwi Prastiti. "Pengaruh Karakteristik Perusahaan terhadap Social Disclosure”. Jurnal Ekonomi Bisnis, TH 16. No. 1, 2011.

Wakid, Nadiah Lutfi, Iwan Triyuwono dan Prihat Assih. "Pengaruh Karakteristik Perusahaan Terhadap Pengungkapan Corporate Social Responsibility Pada Perusahaan Manufaktur Yang Terdaftar Di Bursa Efek Indonesia", Jurnal Program Pascasarjana Fakultas Ekonomi dan Bisnis Universitas Brawijaya, 2012.

www.idx.co.id. Diakses pada bulan Mei, 2015. 